Chapter 5

\title{
Crude Oil Biodegradation in the Marine Environments
}

\author{
Mehdi Hassanshahian and Simone Cappello \\ Additional information is available at the end of the chapter \\ http://dx.doi.org/10.5772/55554
}

\section{Introduction}

Petroleum is a viscous liquid mixture that contains thousands of compounds mainly consisting of carbon and hydrogen. Oil fields are not uniformly distributed around the globe, but being in limited areas such as the Persian Gulf region. The world production of crude oil is more than three billion tons per year, and about the half of this is transported by sea. Consequently, the international transport of petroleum by tankers is frequent. All tankers take on ballast water which contaminates the marine environment when it is subsequently discharged. More importantly, tanker accidents exemplified by that of the Exxon Valdez in Prince William Sound, Alaska, severely affect the local marine environment. Off-shore drilling is now common to explore new oil resources and this constitutes another source of petroleum pollution. However, the largest source of marine contamination by petroleum seems to be the runoff from land. Annually, more than two million tons of petroleum is estimated to end up in the sea. Fortunately, petroleum introduced to the sea seems to be degraded either biologically or abiotically.

\section{The composition of crude oil}

Petroleum has been known for several years to occur in the surface seepage and was first obtained in pre-Christian times by the Chinese. The modern petroleum industry had its beginning in Romania and in a well-sunk in Pennsylvania by Colonel E. A. Drake in 1859 [1]. The principal early use of the product of the petroleum industry was for the replacement of expensive whale oil for lighting. Today, its consumption as a fuel and its dominance in the world market as a source of chemicals has diversified tremendously.

Petroleum is defined as any mixture of natural gas, condensate, and crude oil. Crude oil which is a heterogeneous liquid consisting of hydrocarbons comprised almost entirely of the elements 
hydrogen and carbon in the ratio of about 2 hydrogen atoms to 1 carbon atom. It also contains elements such as nitrogen, sulfur and oxygen, all of which constitute less than $3 \%(\mathrm{v} / \mathrm{v})$.

There are also trace constituents, comprising less than $1 \%(\mathrm{v} / \mathrm{v})$, including phosphorus and heavy metals such as vanadium and nickel. Crude oils could be classified according to their respective distillation residues as paraffins, naphthenes or aromatics and based on the relative proportions of the heavy molecular weight constituents as light, medium or heavy. Also, the composition of crudes may vary with the location and age of an oil field, and may even be depth dependent within an individual well. About $85 \%$ of the components of all types of crude oil can be classified as either asphalt base, paraffin base or mixed base. Asphalt base contain little paraffin wax and an asphaltic residue [2].The sulfur, oxygen and nitrogen contents are often relatively higher in comparison with paraffin base crudes, which contain little or no asphaltic materials. Mixed crude oil contains considerable amount of oxides of nitrogen and asphalt [2].

Crude oil is perhaps the most complex mixture of organic compounds that occurs on earth. Recent advances in ultra-high-resolution mass spectrometry have allowed the identification of more than 17,000 distinct chemical components, and the term petroleomics has been coined to express this newly uncovered complexity [3]. Furthermore, crude oil is not a homogeneous mat erial, and different crude oils have a range of chemical and physical properties that affect their susceptibility to biodegradation and their environmental fate. Within this complexity, however, crude oil can be classified into four main operationally defined groups of chemicals: the saturated hydrocarbons and the aromatic hydrocarbons, and the more polar, non-hydrocarbon components the resins and the asphaltenes. Light oils are typically high in saturated and aromatic hydrocarbons, with a smaller proportion of resins and asphaltenes. Heavy oils, which result from the biodegradation of crude oil under anoxic conditions in situ in petroleum reservoirs, have a much lower content of saturated and aromatic hydrocarbons and a higher proportion of the more polar chemicals, the resins and asphaltenes [4] (figure 1). Biodegradation of crude oil in surface environments results in similar changes in crude oil composition and the loss of saturated and aromatic hydrocarbons, together with an increase in the relative abundance of the polar fractions (which are more resistant to biodegradation), is a characteristic signature of crude-oil biodegradation. Because saturated hydrocarbons constitute the largest fraction of crude oil by mass, the biodegradation of saturated hydrocarbons is quantitatively the most important process in the removal of crude oil from the environment. Nevertheless, the aromatic hydrocarbons and polar fractions, which are more toxic and persistent, could be of greater long-term environmental significance [5].

\section{Oil pollution as an environmental problem}

It is no exaggeration that oil fuels the world's economy, and it is used on a staggering scale. World production was some $80 \mathrm{Mbbl}$ (11 Mt/day) by the end of 2000, and this is expected to increase by $1.9 \%$ year in the next decade [6, 7]. Approximately $40 \%$ of the world's oil travels by water at some time between its production and final consumption, and again the volumes 
$n$-alkanes

$\mathrm{C}-\mathrm{C}-\mathrm{C}-\mathrm{C}-\mathrm{C}$<smiles>CC(C)CC(C)C(C)C</smiles>

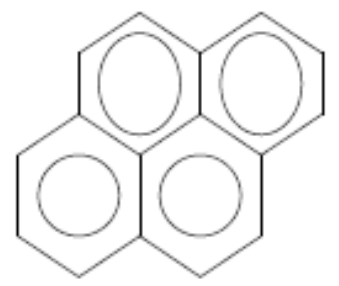

Cycloalkanes

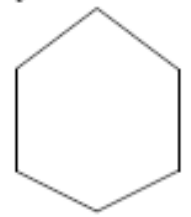

Aromatic hydrocarbon Condensed aromatic hydrocarbon

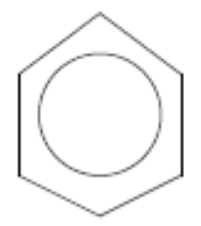

Pyridine

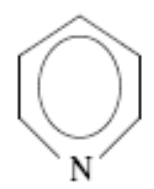

Naphthenic acid

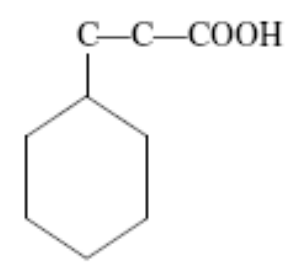

Phenol

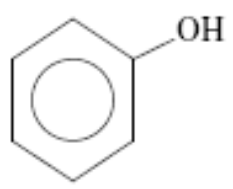

$\mathrm{OH}$

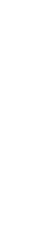


The marine environment is subject to contamination by organic pollutants from a variety of sources. Organic contamination results from uncontrolled releases from manufacturing and refining installations, spillages during transportation, direct discharge from effluent treatment plants and run-off from terrestrial sources.

In quantitative terms, crude oil is one of the most important organic pollutants in marine environments and it has been estimated that worldwide some where between 1.7 and $8.8^{\prime} 106$ tons of petroleum hydrocarbons impact marine waters and estuaries annually [7]. Large oil spills, such as the Exxon Valdez and Sea Empress incidents, invariably capture media attention but such events are relatively rare; however, a substantial number of smaller releases of petroleum hydrocarbons occur regularly in coastal waters. Around the coast of the UK alone, between the years of 1986 and 1996, 6,845 oil spills were reported. Of these, 1,497 occurred in environmentally sensitive areas or were of sufficient magnitude to require clean-up (23). As a consequence of the importance of oil spills relative to other sources of organic contaminants in the marine environment, there is a large body of research on oil-spill bioremediation. Furthermore, studies of oiled shorelines have been far more numerous than open water studies, which have often been equivocal [11, 12].

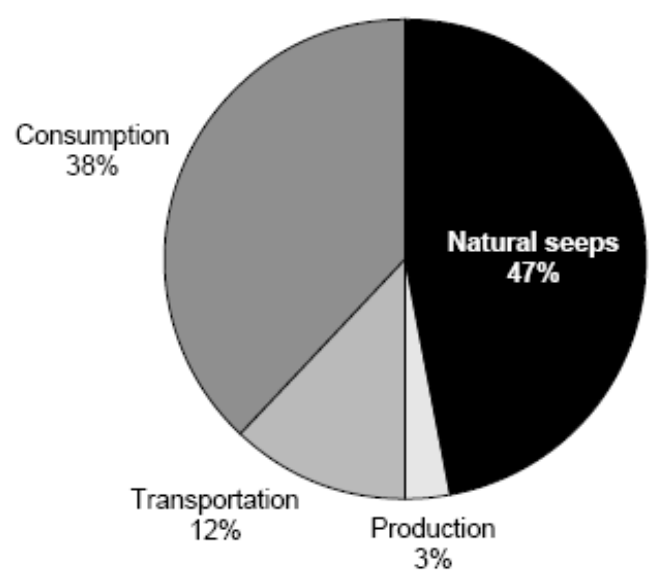

Figure 2. Sources of oil into the sea.

\section{The fate of oil in the marine environment}

The fate of petroleum in marine ecosystems has been intensively studied [5]. Crude oil and petroleum distillate products introduced to the marine environment are immediately subject to a variety of physical and chemical, as well as biological, changes (figure 3) [13].

Abiological weathering processes include evaporation, dissolution, dispersion, photochemical oxidation, water-in-oil emulsification, adsorption onto suspended particulate material, 
sinking, and sedimentation. Biological processes include ingestion by organisms as well as microbial degradation [1]. These processes occur simultaneously and cause important changes in the chemical composition and physical properties of the original pollutant, which in turn may affect the rate or effectiveness of biodegradation. The most important weathering process during the first 48 hours of a spill is usually evaporation, the process by which low to mediumweight crude oil components with low boiling points volatilize into the atmosphere. Evaporation can be responsible for the loss of one to two-thirds of an oil spill's mass during this period, with the loss rate decreasing rapidly over time [13].

Roughly one-third of the oil spilled from the Amoco Cadiz, for example, evaporated within the frost 3 days. Evaporative loss is controlled by the composition of the oil, its surface area and physical properties, wind velocity, air and sea temperatures, sea state, and the intensity of solar radiation [14]. The material left behind is richer in metals (mainly nickel and vanadium), waxes, and asphaltenes than the original oil [15]. With evaporation, the specific gravity and viscosity of the original oil also increase. For instance, after several days, spilled crude oil may begin to resemble Bunker C (heavy) oil in composition.

None of the other abiological weathering processes accounts for as significant a proportion of the losses from a spill. For example, the dissolving, or dissolution, of oil in the water column is a much less important process than evaporation from the perspective of mass lost from a spill; dissolution of even a few percent of a spill's mass is unlikely. Dissolution is important, however, because some water soluble fractions of crude oil (e.g., the light aromatic compounds) are acutely toxic to various marine organisms (including microorganisms that may be able to degrade other fractions of oil), and their impact on the marine environment is greater than mass balance considerations might imply $[14,15)$.

Dispersion, the breakup of oil and its transport as small particles from the surface to the water column extremely important process in the disappearance of a surface slick [15]. Dispersion is controlled largely by sea surface turbulence: the more turbulence, the more dispersion. Chemical dispersants have been formulated to enhance this process. Such dispersants are intended as a first-line defense against oil spills that threaten beaches and sensitive habitats such as salt marshes and mangrove swamps although used widely in other countries, dispersants have had trouble being accepted in the United States. The National Research Council has generally approved their use, but effectiveness and, to a lesser degree, toxicity remain concerns. Dispersed oil particles are more susceptible to biological attack than undispersed ones because they have a greater exposed surface area. Hence, dispersants may enhance the rate of natural biodegradation Water-in-oil emulsions, often termed "mousses are formed when seawater, through heavy wave action, becomes entrained with the insoluble components of oil. Such emulsions can form quickly in turbulent conditions and may contain 30 to 80 percent water [16].

Heavier or weathered crudes with high viscosities form the most stable mousses. Mousse will eventually disperse in the water column and/or be biodegraded, but may first sink or become stranded on beaches. A water-in-oil emulsion is more difficult for microorganisms to degrade than oil alone [17]. 


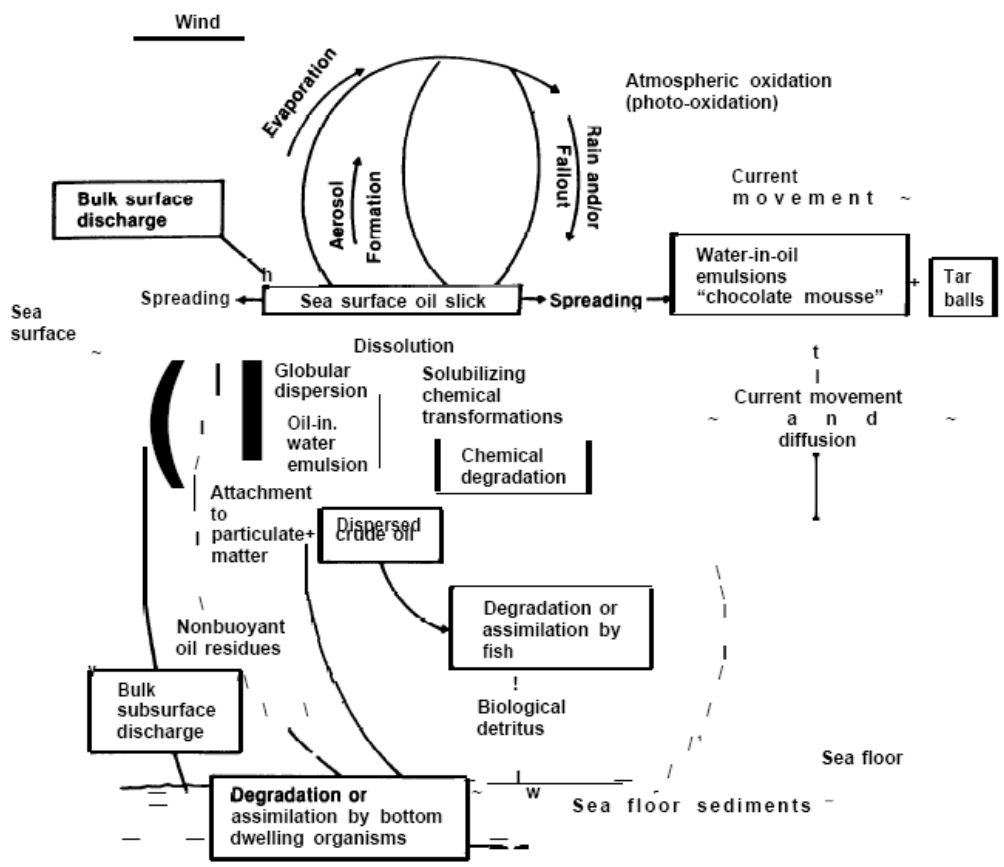

Figure 3. the fate of oil in the marine environment [7].

Mousse formation, for example, has been suggested as a major limiting factor in petroleum biodegradation of the Ixtoc I and Metula spills, probably because of the low surface area of the mousse and the low flux of oxygen and mineral nutrients to the oil-degrading microorganisms within it [17]. Natural biodegradation is ultimately one of the most important means by which oil is removed from the marine environment, especially the nonvolatile components of crude or refined petroleum.

In general, it is the process whereby microorganisms (especially bacteria, but yeasts, fungi, and some other organisms as well) chemically transform compounds such as petroleum hydrocarbons into simpler products. Although some products can actually be more complex, ideally hydrocarbons would be converted to carbon dioxide (i.e., mineralized), nontoxic watersoluble products, and new microbial biomass. The mere disappearance of oil (e.g., through emulsification by living cells) technically is not biodegradation if the oil has not actually been chemically transformed by microbes [17].

The ideal may be difficult to reach, particularly in a reasonably short time, given the recalcitrance of some petroleum fractions to biodegradation (discussed below) and the many variables that affect its rate and extent. Man-made bioremediation technologies are intended to improve the effectiveness of natural biodegradation [17]. 


\section{Response of marine microbial community to oil pollution}

Hydrocarbon-degrading microorganisms usually exist in very low abundance in marine environments. Pollution by petroleum hydrocarbons, however, may stimulate the growth of such organisms and cause changes in the structure of microbial communities in the contaminated area [18]. For example Hassanshahian et al (2010) show that oil contamination can induce major changes in marine microbial communities at Persian Gulf and Caspian Sea, that when the pollution occur the number of crude oil degrading bacteria increased and also inhibit some catalytic enzymes [19].

Identification of the key organisms that play roles in pollutant biodegradation is important for understanding, evaluating and developing in situ bioremediation strategies. For this reason, many efforts have been made to characterize bacterial communities, to identify responsible degraders, and to elucidate the catalytic potential of these degraders. In a natural marine environment, the amounts of nutrients, especially those of nitrogen and phosphorus, are insufficient to support the microbial requirements for growth, especially after a sudden increase in the hydrocarbon level associated with an oil spill. Therefore, nitrogen and phosphorus nutrients are added to a contaminated environment to stimulate the growth of hydrocarbon degrading microorganisms and, hence, to increase the rate of biodegradation of the polluting hydrocarbons $[20,21]$.

\section{Crude oil degrading microorganisms}

Hydrocarbon-degrading bacteria were first isolated almost a century ago [22] and a recent review lists 79 bacterial genera that can use hydrocarbons as a sole source of carbon and energy, as well as 9 cyanobacterial genera, 103 fungal genera and 14 algal genera that are known to degrade or transform hydrocarbons (Table 1) [23, 24].

Despite the difficulty of degrading certain fractions, some hydrocarbons are among the most easily biodegradable naturally occurring compounds. Many more as-yet-unidentified strains are likely to occur in nature [25]. Moreover, these genera are distributed worldwide. All marine and freshwater ecosystems contain some oil-degrading bacteria. No one species of microorganism, however, is capable of degrading all the components of given oil. Hence, many different species are usually required for significant overall degradation. Both the quantity and the diversity of microbes are greater in chronically polluted areas. In waters that have not been polluted by hydrocarbons, hydrocarbon-degrading bacteria typically make up less than 1 percent of the bacterial population, whereas in most chronically polluted systems (harbors, for example) they constitute 10 percent or more of the total population [26].

Hydrocarbon degrading bacteria and fungi are widely distributed in marine, freshwater, and soil habitats. Similarly, hydrocarbon degrading cyanobacteria have been reported [27, 28] although contrasting reports indicated that growth of mats built by cyanobacteria in the Saudi coast led to preservation of oil residues [29]. Typical bacterial groups already known for their 
capacity to degrade hydrocarbons include Pseudomonas, Marinobacter, Alcanivorax, Microbulbifer, Sphingomonas,Micrococcus, Cellulomonas, Dietzia, and Gordonia groups [30]. Molds belonging to the genera Aspergillus, Penicillium, Fusarium, Amorphoteca, Neosartorya, Paecilomyces, Talaromyces, Graphium and the yeasts Candida, Yarrowia and Pichia have been implicated in hydrocarbon degradation [27, 31]. However, reports in literature on the actual numbers of hydrocarbon utilizes are at variance with one another because of the methodological differences used to enumerate petroleum-degrading microorganisms.

Diverse petroleum-degrading bacteria inhabit marine environments. They have often been isolated as degraders of alkanes or of such aromatic compounds as toluene, naphthalene and phenanthrene. Several marine bacteria capable of degrading petroleum hydrocarbons have been newly isolated. These are bacteria of the genera Alcanivorax [32], Cycloclasticus [33], Marinobacter [34], Neptunomonas [25], Oleiphilus [35] and Oleispira [36] within the $\gamma$-Proteobacteria, and of the genus Planococcus within Gram-positive bacteria [37]. These bacteria, with the possible exception of Marinobacter and Neptunomonas, use limited carbon sources with a preference for petroleum hydrocarbons and are thus 'professional hydrocarbonoclastic' bacteria. For example, Alcanivorax strains grow on n-alkanes and branched alkanes, but cannot use any sugars or amino acids as carbon sources. Similarly, Cycloclasticus strains grow on the aromatic hydrocarbons, naphthalene, phenanthrene and anthracene, whereas Oleiphilus and Oleispira strains grow on the aliphatic hydrocarbons, alkanoles and alkanoates. Many 'nonprofessional' hydrocarbonoclastic bacteria have been isolated: for example, Vibrio, Pseudoalteromonas, Marinomonas and Halomonas have been isolated as marine bacteria capable of degrading phenanthrene or chrysene [38].

Some hydrocarbon-degrading bacteria isolated from marine environments have been classified into several genera that include terrestrial hydrocarbon degrading bacteria: namely, naphthalene-degrading Staphylococcus and Micrococcus [39], 2-methylphenanthrene-degrading Sphingomonas [40] and alkane-degrading Geobacillus [41]. Although some Cycloclasticus strains have been isolated using the extinction culturing method, other strains were isolated by conventional enrichment techniques with petroleum hydrocarbons used as the sources of carbon and energy. Therefore, a greater variety of hydrocarbon-degrading marine bacteria are likely to be isolated if hydrocarbon enrichment is done in combination with the specific resuscitation techniques already described.

\section{Pathway for biodegradation of some compartment of crude oil}

\subsection{Fundamental reactions of aerobic degradation}

The fundamental reactions of the aerobic hydrocarbon decomposition have been well known for several decades. Suitable surveys are contained in the books of [42, 43]. Even though many details have been published since, such as the degradation of aliphatic alkenes [44], the fundamental steps are still valid and enable us to understand the dependence of the processes on environmental conditions (Figures 4 and 5). Experiments on the laboratory scale as well as 


\begin{tabular}{ccc}
\hline Bacteria & Yeast & Fungi \\
\hline Achromobacter & Candida & Aspergillus \\
\hline Acinetobacter & Cryptococcus & Cladosporium \\
\hline Alcanivorax & Debaryomyces & Corollasporium \\
\hline Alcaligenes & Hamsenula & Cunninghamella \\
\hline Bacillus & Pichia & Dendryphiella \\
\hline Brevibacterium & Rhodotorula & Gliocladium \\
\hline Burkholderia & Saccharomyces & Luhworthia \\
\hline Corynebacterium & Sporobolomyces & Penicillium \\
\hline Flavobacterium & Torulopsis & Varicospora \\
\hline Mycobscterium & Trichosporon & Verticillium \\
\hline Nocardia & Yarrowia & \\
\hline Pseudomonas & & \\
\hline Rhodococcus & & \\
\hline Sphingomonas & & \\
\hline
\end{tabular}

Table 1. Crude-oil degrading microorganisms

observation of polluted sites have made it possible to estimate the impact of oil degradation on sediment.

The key step of hydrocarbon degradation is the addition of one oxygen atom, in some cases, two oxygen atoms, to the hydrocarbon molecule, which is then converted to an alkanol (in the case of aliphatic hydrocarbons) or to a phenol (in the case of aromatic molecules). In some species, an epoxide is the first intermediate. This activation makes the hydrocarbon more soluble in water, marks a reactive site, and introduces a reactive site for the next reactions. The reaction requires energy, which is typically generated via the oxidation of a reduced biological intermediate such as NADH, which itself is reoxidized by an electron acceptor. For the degradation of alkanes, different enzyme systems are known which carry out the primary attack. An omega-hydroxylase system consisting of three proteins (the rubredoxin reductase, a rubredoxin and an omega-hydroxylase) was isolated and characterized from Pseudomonas [45]. In some bacterial or fungal species as well as in mammalian cells, there are enzyme systems which depend on cytochrome P450 acting as a terminal oxidase. The main intermediates of the alkane degradation are fatty acids, which are produced from the alkanols via aldehydes. These acids can be further decomposed by the pathway typical of physiologica carboxylic acid degradation, in which the molecule is shortened stepwise. However, fatty acids can also be excreted by the cells and accumulate in the environment. 
Once released, they can produce ambiguous effects. On the one hand, fatty acids can serve as a carbon source for bacteria of a community, thus enhancing the hydrocarbon degradation. On the other hand, fatty acids (chain length $14 \mathrm{C}$ ) can inhibit growth and hydrocarbon metabolism because they interfere with the cell membrane [47]. This provokes a toxic effect and reduces growth. Different degradative pathways have been demonstrated for aromatic substrates. The choice of the pathway depends on the type of the organism and/or on the type of the aromatic molecule, especially on its substituents and (in the case of polyaromatic molecules, PAH) on the number of rings [48]. For an overview of the fundamental possibilities of PAH biodegradation, three different metabolic routes considered to be the main pathways are summarized here.

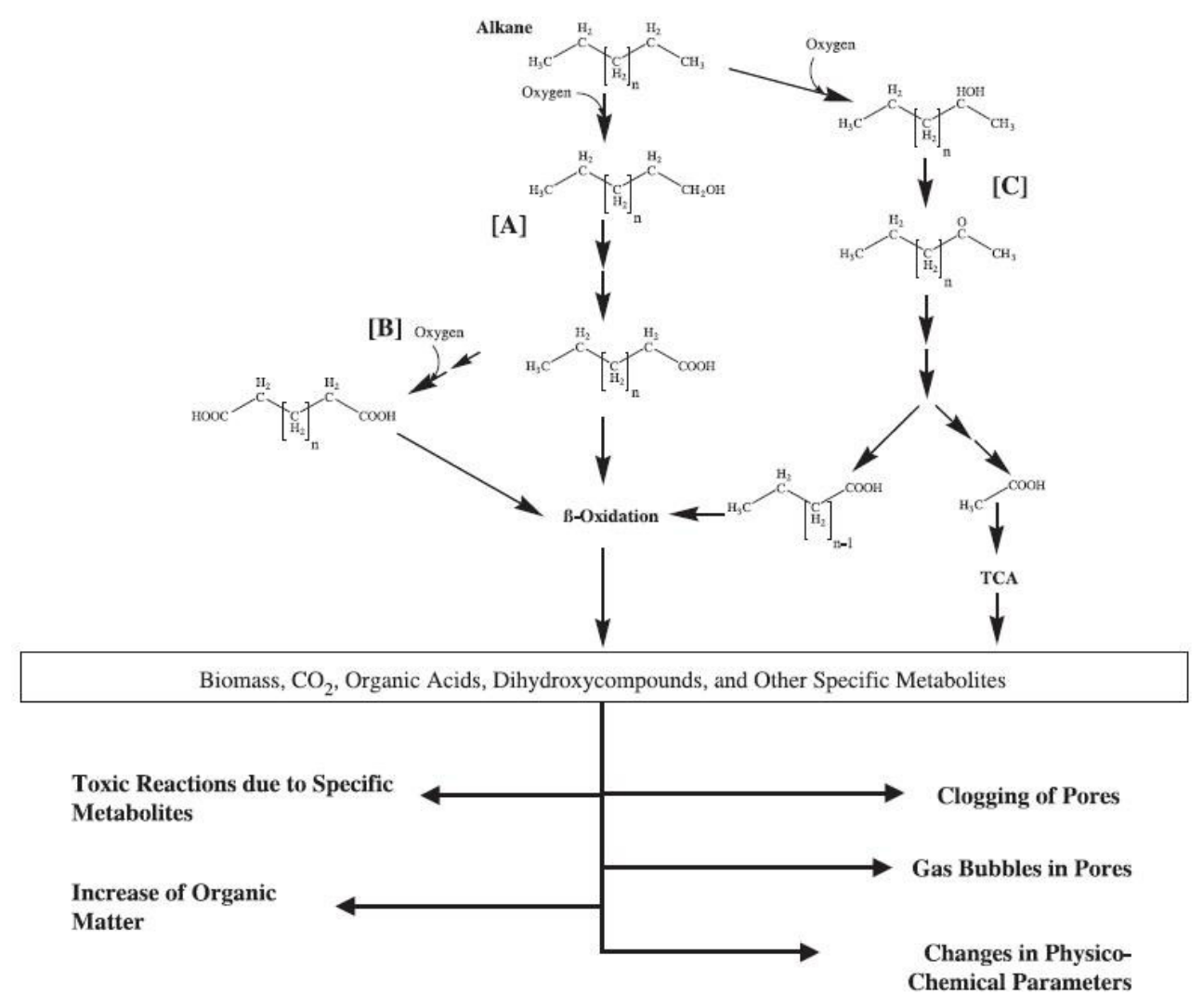

Figure 4. Aerobic degradation of crude oil hydrocarbons with its environmental impact. Biodegradation of n-alkanes: metabolism begins with the activity of a monooxygenase which introduces a hydroxyl group into the aliphatic chain [A]-monoterminal oxidation, [B]-biterminal oxidation, [C]- subterminal oxidation); TCA-tricarboxylic acid cycle [44] 


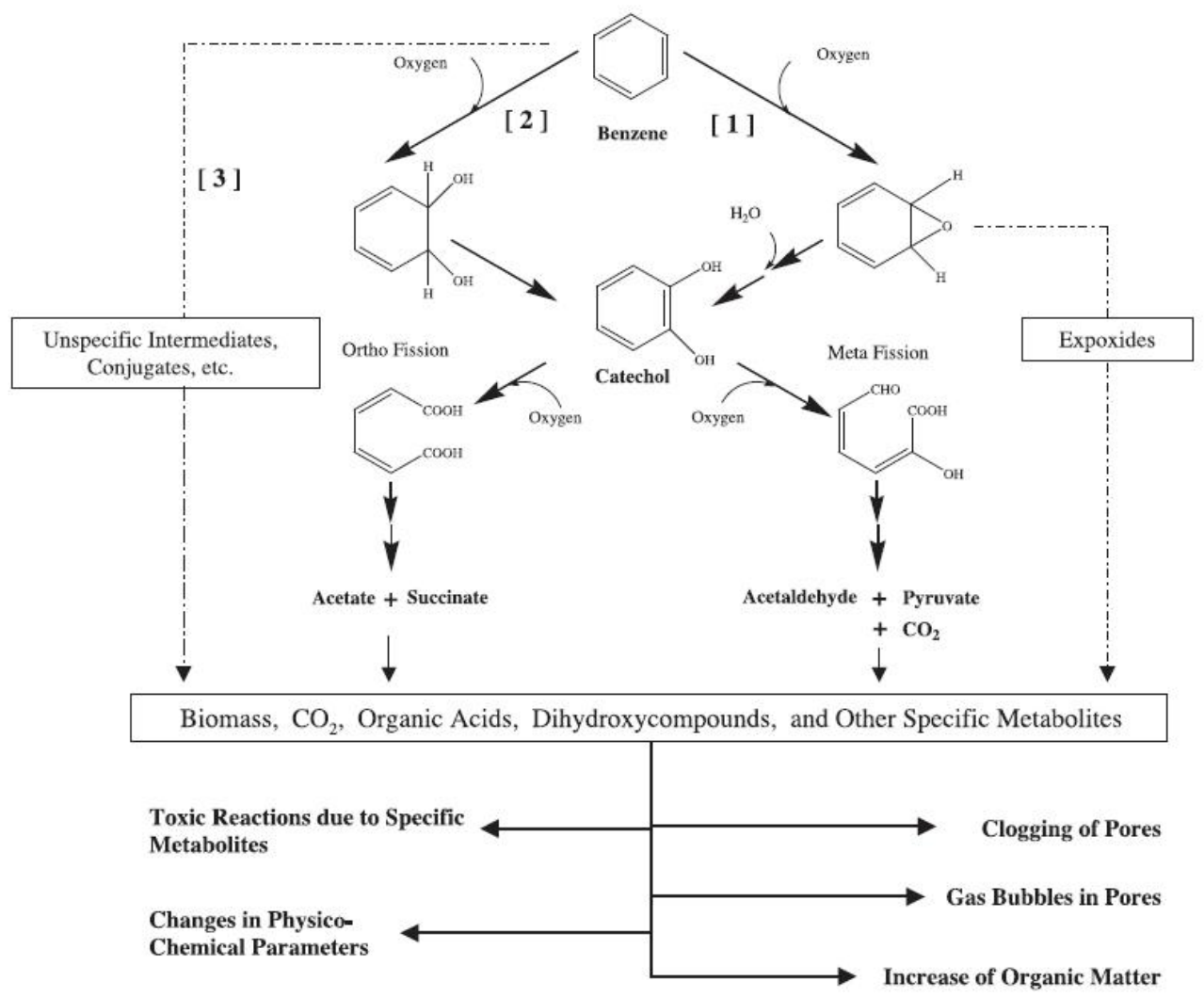

Figure 5. Biodegradation of aromatic hydrocarbons: metabolism begins with the activity of a monooxygenase [1] or a dioxygenase [2] which introduce one or two atoms of oxygen; it can also begin with unspecific reactions [3] [48].

\subsection{Complete mineralization or the dioxygenase pathway}

This pathway is taken mainly by bacteria. The monoaromatic molecule or one ring of the polyaromatic system is attacked by a dioxygenase, and the molecule is oxidized stepwise via formation of a diol and subsequent ring cleavage. Pyruvate is one of the main intermediates of the pathway. The main products are biomass and carbon dioxide. An accumulation of deadend products is rare and occurs mostly when cells are deficient in their degradation pathway. The disadvantage of this pathway is that only ring systems of up to four rings are mineralized. Systems with a higher number of rings seem to be recalcitrant [49].

\subsection{Cometabolic transformation or the monooxygenase pathway}

This pathway has been mainly demonstrated for yeasts and fungi, but it also occurs in bacteria and in some algae. The respective PAH-degrading species can only perform the 
degradation if a compound is available which can serve as a source of carbon and energy. The characteristic enzymes which perform ring cleavage are monooxygenases (e.g., Cyt P450). The monooxygenase activity results in the formation of an epoxide which is highly reactive, resulting in toxic or mutagenic activity. Epoxides may also be transformed to trans-dihydrodiols. The latter have not been metabolized further in pure cultures in the laboratory and have to be regarded as dead-end products. However, no such metabolites have been detected in soil or in sediment [50].

\subsection{Unspecific oxidation via radical reactions}

The wood-destroying white rot fungi, e.g., have been shown to destroy the structure of lignin via the activity of extracellular peroxidases and phenol oxidases. They attack the phenolic molecule structure by a nonspecific action, thus also attacking other aromatic structures such as PAH. The type of cleavage product is not predictable. Frequent metabolites of PAHs are quinones, quinoles, and ring systems with a ring number lower than that of the original substance. These compounds may be incorporated into sediments and alter the sediment structure [51].

\subsection{Anaerobic hydrocarbon degradation}

For many decades, it was assumed that hydrocarbons undergo biodegradation only in the presence of molecular oxygen. However, in 1988 Evans and Fuchs [50] published a review paper on the anaerobic degradation of aromatic compounds, and Aeckersberg et al. (1991) [52] reported on a sulphate-reducing bacterium able to anaerobically mineralize hexadecane. Since that time, a great deal of work has been done on the anaerobic degradation of aliphatic and aromatic hydrocarbons. It has been demonstrated that anaerobic hydrocarbon degradation is not uncommon in nature although, in most cases it is considerably slower than aerobic degradation. Denitrifying, sulfate-reducing, and iron (III)-reducing strains collected at different sites (terrestrial, aquifers, fresh-water and marine systems) are able to anaerobically metabolize hydrocarbons. The same has been demonstrated for the phototrophic bacterium Blastochloris sulfoviridis strain ToP1, which uses light as an energy source [53]. Even methanogenic consortia have been shown to degrade hydrocarbons [54,55]. The metabolic routes of alkane degradation seem to function differently and are not completely understood yet. Several authors have discussed a terminal or sub terminal addition of a one-carbon moiety or a fumarate molecule to the alkane as an activation mechanism [56, 57] (Figure 6). For aromatic molecules, it has been demonstrated that alkyl benzenes which have a methyl group as a side chain undergo an enzymes addition of fumarate, most likely via a radical mechanism. This was demonstrated for toluene. Alkyl benzenes with side chains of two or more carbon atoms are activated by dehydrogenation of the side chain.

This has been shown for ethyl- and propylbenzene [53]. A scheme of the anaerobic degradation is shown in Figure (7). 

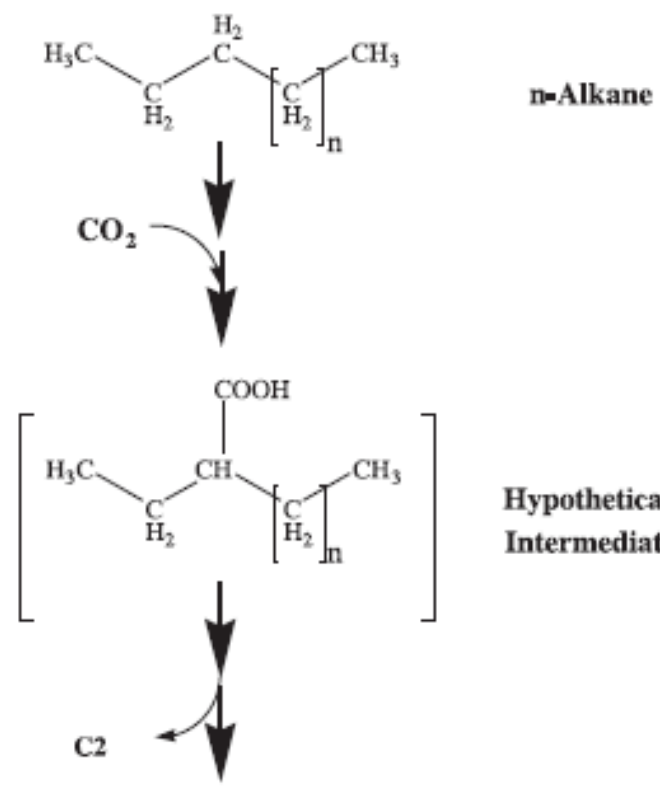

\section{Hypothetical \\ Intermediate}<smiles>CCCCCC(C)CCC(=O)O</smiles>

Fatty Acid
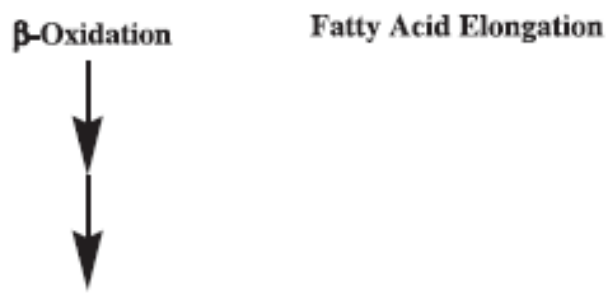

\section{TCA}
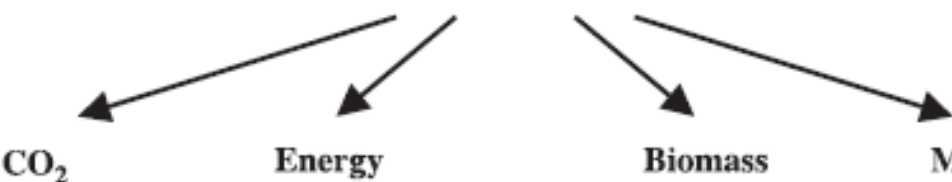

Biomass

\section{Metabolites}

Figure 6. Proposed pathway for anaerobic degradation of n-alkanes; activation via addition of a C1-moiety (subterminal carboxylation at C3). Pathway according to So et al. (2003); TCA tricarboxylic acid cycle [55]. 

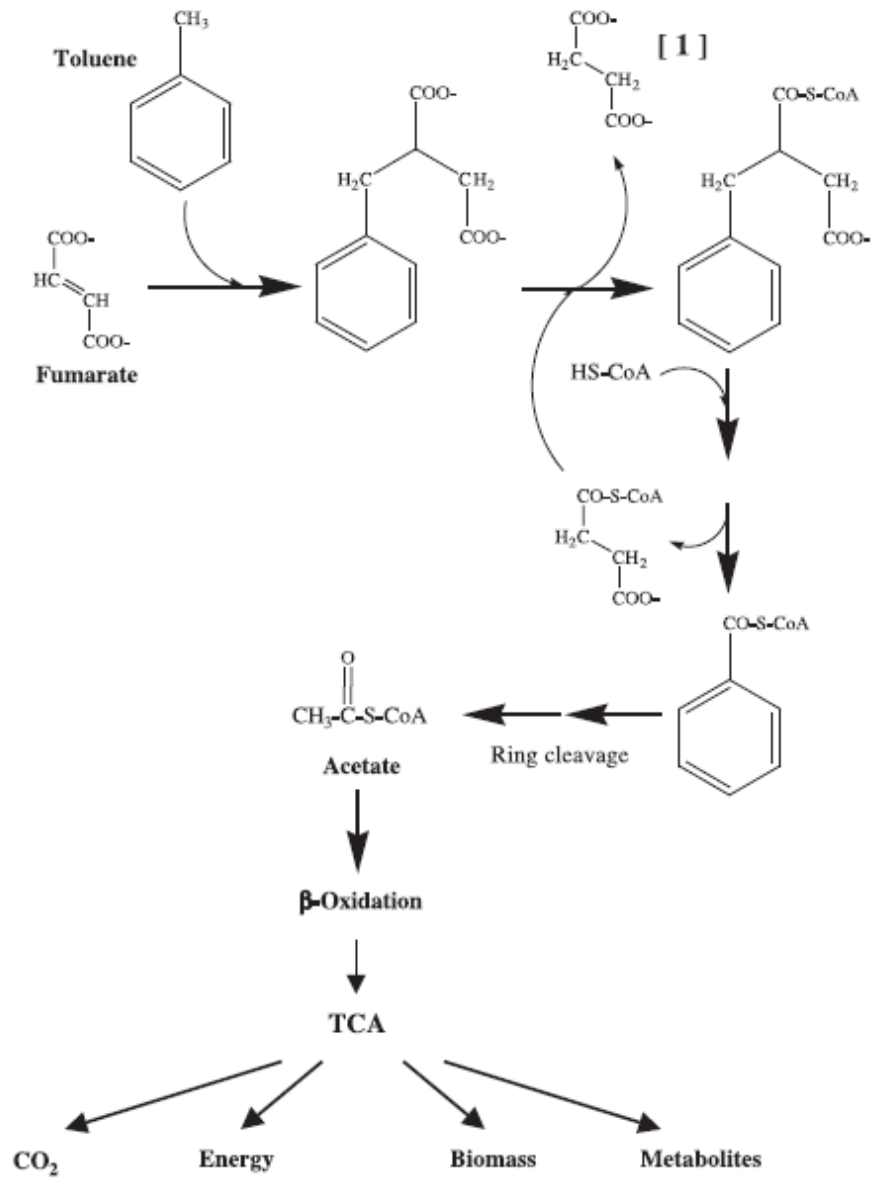

Figure 7. Proposed pathways of anaerobic degradation of aromatic hydrocarbons; activation via addition of fumarate, [1] - succinate. Pathways according to Spormann and Widdel (2000), and Wilkes et al. (2002); TCA-tricarboxylic acid cycle [55].

\subsection{Competing processes}

The ideal preconditions for biodegradation cited above occur only rarely, e.g., in the case of a rough and nutrient-rich sea or on energy-rich tidal flats. Mostly, however, the reality of oil spills is very different. The ideal steps are rendered difficult, slowed down, or made impossible by competing processes. Such influences are exemplified by the case studies. Heavy oils or heavy oil products such as heavy fuel oil or bunker oil $\mathrm{C}$ behave very differently from the light oils described above. Heavy oils incorporate suspended matter, debris, biomass, and even 
garbage, which increases their viscosity and decreases their biodegradability. Due to their viscosity, the energy needed to emulsify heavy oils is very great. Solar irradiation causes the evaporation of the light components and photodecomposition, resulting in unpredictable compounds. Oil carpets are formed. Where they meet the coastline, beaches are covered. Their removal by natural forces is very slow or even impossible, and technical purification is expensive and troublesome. Biological degradation is extremely slow because the low oil surface to volume ratio limits the bioavailability of the oil.

Oil biodegradation works well on the open sea but proceeds differently on beaches. Vast areas of tidal beaches can be covered by oil when there is wind onshore during the ebb tide. If this oil cover is subjected to strong sun irradiation, the oil does not float up during the next flood because the light components have evaporated. The sediment is soaked with the sticky oil. Tides and wind add further sediment, and the initially liquid, later viscous, pollutant becomes more and more solidified [58].

This solidified material is only slowly attacked by waves, hampering biodegradation because the available surface is too small. Irradiation and the catalyzing capacity of particle surfaces help to convert a part of the original mixture of small molecules into high molecular mass material of low solubility, forming tar and finally asphalt. Such products appear as geological rather than organic matter. Experience has shown that it is difficult for organisms to settle on oil layers. The Persian Gulf spill presented a new experience in so far as thick and vital cyanobacterial mats developed on oil covers within a few months, introducing biomass as well as Aeolian and hydrodynamic sediments fixed by the growing mats. This observation was welcomed initially [59] but then turned out to be disappointing because biodegradation was not favored [60]. In some cases, colonization opened the oil crusts; in other cases, it formed stable covers which prevented the access of oxygen to deeper layers, helping to preserve the pollution. The latter clearly transformed the polluted system, resulting in geo-biological matter that had never been present before. This geo-biological matter dominated the sites after the spill. In the upper eulittoral and the lower supra tidal zone, calcareous incrustation and solid salt supported the conversion of the oil into rock-like matter with a life span of 10 or more years [61].

\section{Factors affected crude oil biodegradation in marine environment}

Environmental variables can also greatly influence the rate and extent of biodegradation. Variables such as oxygen and nutrient availability can often be manipulated at spill sites to enhance natural biodegradation (i.e., using bioremediation). Other variables, such as salinity, are not usually controllable. The great extent to which a given environment can influence biodegradation accounts for some of difficulty in accurately predicting the success of bioremediation efforts. Lack of sufficient knowledge about the effect of various environmental factors on the rate and extent of biodegradation is another source of uncertainty [19, 62]. 


\subsection{Oxygen}

Oxygen is one of the most important requirements for microbial degradation of hydrocarbons. However, its availability is rarely a rate-limiting factor in the biodegradation of marine oil spills. Microorganisms employ oxygen-incorporating enzymes to initiate attack on hydrocarbons. Anaerobic degradation of certain hydrocarbons (i.e., degradation in the absence of oxygen) also occurs, but usually at negligible rates. Such degradation follows different chemical paths, and its ecological significance is generally considered minor. For example, studies of sediments impacted by the Amoco Cadiz spill found that, at best, anaerobic biodegradation is several orders of magnitude slower than aerobic biodegradation. Oxygen is generally necessary for the initial breakdown of hydrocarbons, and subsequent reactions may also require direct incorporation of oxygen. Requirements can be substantial; 3 to 4 parts of dissolved oxygen are necessary to completely oxidize 1 part of hydrocarbon into carbon dioxide and water. Oxygen is usually not a factor limiting the rate of biodegradation on or near the surface of the ocean, where it is plentiful and where oil can spread out to provide a large, exposed surface area. Oxygen is also generally plentiful on and just below the surface of beaches where wave and tide action constantly assist aeration. When oxygen is less available, however, the rates of biodegradation decrease. Thus, oil that has sunk to the sea floor and been covered by sediment takes much longer to degrade. Oxygen availability there is determined by depth in the sediment, height of the water column, and turbulence (some oxygen may also become available as the burrowing of bottom-dwelling organisms helps aeration) [63, 64]. Low-energy beaches and fine-grained sediments may also be depleted in oxygen; thus, the rate of biodegradation may be limited in these areas. Pools of oil are a problem because oxygen is less available below their surfaces. Thus, it may be preferable to remove large pools of oil on beaches, as was done in Alaska, before attempting bioremediation [18, 65].

\subsection{Nutrients}

Nutrients such as nitrogen, phosphorus, and iron play a much more critical role than oxygen in limiting the rate of biodegradation in marine waters. Several studies have shown that an inadequate supply of these nutrients may result in a slow rate of biodegradation [52]. Although petroleum is rich in the carbon required by microorganisms, it is deficient in the mineral nutrients necessary to support microbial growth [53]. Marine and other ecosystems are often deficient in these substances because non-oil degrading microorganisms (including phytoplankton) consume them in competition with the oil degrading species. Also, phosphorus precipitates as calcium phosphate at the $\mathrm{pH}$ of seawater. Lack of nitrogen and phosphorus is most likely to limit biodegradation, but lack of iron or other trace minerals may sometimes be important. Iron, for instance, is more limited in clear offshore waters than in sediment-rich coastal waters Scientists have attempted to adjust nutrient levels (e.g., by adding nitrogen- and phosphorus-rich fertilizers) to stimulate biodegradation of petroleum hydrocarbons. This is the experimental bioremediation approach used recently on about 110 miles of beaches in Prince William Sound, Alaska. Researchers have also experimented with alternative methods of applying nutrients. Given the necessity of keeping nutrients in contact with oil, the method of application is itself likely to be an important factor in the success of bioremediation $[65,66]$. 


\subsection{Temperature}

The temperature of most seawater is between -2 and $35{ }^{\circ} \mathrm{C}(55)$. Biodegradation has been observed in this entire temperature range, and thus in water temperatures as different as those of Prince William Sound and the Persian Gulf. The rates of biodegradation are fastest at the higher end of this range and usually decrease-sometimes dramatically in very cold climateswith decreasing temperature. One experiment showed that a temperature drop from 25 to 5 ${ }^{\circ} \mathrm{C}$ caused a tenfold decrease in response [56]. At low temperature, the rate of hydrocarbon metabolism by microorganisms decreases [57]. Also, lighter fractions of petroleum become less volatile, thereby leaving the petroleum constituents that are toxic to microbes in the water for a longer time and depressing microbial activity. Petroleum also becomes more viscous at low temperature. Hence, less spreading occurs and less surface area is available for colonization by microorganisms. In temperate regions, seasonal changes in water temperature affect the rate of biodegradation, but the process continues year-round.

\subsection{Other factors}

Several variables, including pressure, salinity, and $\mathrm{pH}$ may also have important effects on biodegradation rates. Increasing pressure has been correlated with decreasing rates of biodegradation; therefore, pressure may be very important in the deep ocean $[67,68]$. Oil reaching great ocean depths degrades very slowly and, although probably of little concern, is likely to persist for a long time [59]. Microorganisms are typically well adapted to cope with the range of salinities common in the world's oceans. Estuaries may present a special case because salinity values, as well as oxygen and nutrient levels, are quite different from those in coastal or ocean areas. However, there is little evidence to suggest that microorganisms are adversely affected by other than hyper saline environments. Extremes in $\mathrm{pH}$ affect a microbe's ability to degrade hydrocarbons. However, like salinity, $\mathrm{pH}$ does not fluctuate much in the oceans it remains between 7.6 and 8. 1 and does not appear to have an important effect on biodegradation rates in most marine environments. In salt marshes, however, the $\mathrm{pH}$ maybe as low as 5.0, and thus may slow the rate of biodegradation in these habitats $[69,70]$.

\section{Biodegradation strategy for crude oil removal from marine environment (biostimulation and bioaugmentation)}

Bioremediation technologies for responding to marine oil spills may be divided into three discrete categories:

1. Nutrient enrichment (Biostimulation)

2. Seeding with naturally occurring microorganisms (Bioaugmentation)

3. Seeding with genetically engineered microorganisms (Bioaugmentation with GEMs) 


\subsection{Nutrient enrichment (biostimulation)}

Of all the factors that potentially limit the rate of petroleum biodegradation in marine environments, lack of an adequate supply of nutrients, such as nitrogen and phosphorus, is probably the most important and perhaps the most easily modified. Nutrient enrichment (sometimes called nutrition) also has been more thoroughly studied than the other two approaches, especially now that EPA, Exxon, and the State of Alaska have carried out extensive nutrient enrichment testing on beaches polluted by oil from the Exxon Valdez [71]. In part for these reasons, many scientists currently view nutrient enrichment as the most promising of the three approaches for those oil spill situations in which bioremediation could be appropriate. This approach involves the addition of those nutrients that limit biodegradation rates (but not any additional microorganisms) to a spill site and conceptually is not much different than fertilizing a lawn [71]. The rationale behind the approach is that oil-degrading microorganisms are usually plentiful in marine environments and well adapted to resisting local environmental stresses. However, when oil is released in large quantities, microorganisms are limited in their ability to degrade petroleum by the lack of sufficient nutrients. The addition of nitrogen, phosphorus, and other nutrients is intended to overcome these deficits and allow petroleum biodegradation to proceed at the optimal rate. Experiments dating to at least 1973 have demonstrated the potential of this approach. Researchers, for example, have tested nutrient enrichment in near shore areas off the coast of New Jersey, in Prudhoe Bay, and in several ponds near Barrow, Alaska. In each case, the addition of fertilizer was found to stimulate biodegradation by naturally occurring microbial populations. The recent nutrient enrichment experiments in Alaska provided a wealth of experimental data about bioremediation in an open environment (box B) [72]. Since previous research findings had already demonstrated the general value of this approach, the experiments were intended to determine for one type of environment how much enhancement of natural biodegradation could be expected and to evaluate the most effective methods of application. The results provided additional evidence that application of nutrients could significantly enhance the natural rate of biodegradation on and below the surface of some beaches. As a result, Exxon was authorized by the Coast Guard on-scene coordinator, in concurrence with the Alaska Regional Response Team, to apply fertilizers to the oiled beaches in Prince William Sound [73]. To date, about 110 miles of shoreline have been treated with nutrients, and a monitoring program has been established. Without additional research, however, it is premature to conclude that nutrient enrichment will be effective under all conditions or that it will always be more effective than other bioremediation approaches, other oil spill response technologies, or merely the operation of natural processes. The results of the Alaska experiments were influenced by the beach characteristics (mostly rocky beaches, well-washed by wave and tide action), the water temperature (cold), the kind of oil (Prudhoe Bay crude), and the type and quantity of indigenous microorganisms in Prince William Sound. Few detailed analyses or performance data are yet available for different sets of circumstances. One smaller-scale test using the same fertilizer as in Alaska was recently conducted on beaches in Madeira polluted by the Spanish tanker Aragon. Results in this very different setting and with a different type of oil were not especially encouraging. Researchers speculated that the unsatisfactory results could have been due to differences in the type of oil, the concentration of fertilizer used the lower initial bacterial 
activity, and/or different climatic conditions. At the same time, Exxon recently used what it learned in Alaska to help degrade subsurface no. 2 heating oil spilled in a wildlife refuge bordering the Arthur Kill at Prall's Island, New Jersey. An innovative aspect of this application was the use of two trenches parallel to the beach in which to distribute fertilizer. Nutrients were dissolved with the incoming tide and pulled down the beach with the ebb tide, enabling a more even distribution than point sources of fertilizer. Exxon reports those 3 months after applying fertilizers, the oil in the treated zone had been reduced substantially relative to that in an untreated control zone $[74,75,76]$.

\subsection{Seeding with naturally occurring microorganisms (bioaugmentation)}

Seeding (also called inoculation) is the addition of microorganisms to a polluted environment to promote increased rates of biodegradation. The inoculums maybe a blend of non indigenous microbes from various polluted environments, specially selected and cultivated for their oildegrading characteristics, or it may be a mix of oil-degrading microbes selected from the site to be remediate and mass-cultured in the laboratory or in on-site bioreactors. Nutrients would usually also accompany the seed culture. The rationale for adding microorganisms to a spill site is that indigenous microbial populations may not include the diversity or density of oildegraders needed to efficiently degrade the many components of a spill. Some companies that advocate seeding with microorganisms also claim that commercial bacterial blends can be custom-tailored for different types of oil in advance of a spill, that the nutritional needs and limitations of seed cultures are well understood, that microbes can easily be produced in large quantities for emergency situations, and that seed cultures can be stored, ready for use, for up to 3 years.

The value of introducing nonindigenous microorganisms to marine environments is still being evaluated. With some exceptions, the scientilc community has not been encouraging about the promise of seeding marine oil spills. Controlled studies have not been conducted in such settings, so no data are available to evaluate the effectiveness of this approach. Many scientists question the necessity of adding microbes to a spill site because most locales have sufficient indigenous oil-degrading microbes, and in most environments biodegradation is limited more by lack of nutrients than by lack of microbes [72]. At many spill sites, a very low level of oil is often present as "chronic" input, inducing oil-degrading capability in naturally occurring microorganisms. Moreover, the requirements for successful seeding are more demanding than those for nutrient enrichment. Not only would introduced microbes have to degrade petroleum hydrocarbons better than indigenous microbes, they would also have to compete for survival against a mixed population of indigenous organisms well adapted to their environment. They would have to cope with physical conditions (such as local water temperature, chemistry, and salinity) and predation by other species, factors to which the native organisms are likely to be well adapted [77].

The time required for introduced microbes to begin metabolizing hydrocarbons is also important. If a seed culture can stimulate the rapid onset of biodegradation, it would have an advantage over relying on indigenous microbes that may take time to adapt. Despite some claims, seed cultures have not yet demonstrated such an advantage over indigenous microbial 
communities. Seed cultures are typically freeze-dried (and therefore dormant) and require time before they become active [73].

Seed cultures also must be genetically stable, must not be pathogenic, and must not produce toxic metabelites. Some laboratory and small-scale experiments in controlled environments have demonstrated that seeding can promote biodegradation [75].

However, it is exceedingly difficult to extrapolate the results of such tests to open water where many more variables enter the picture. Results of experimental seeding of oil spills in the field have thus far been inconclusive. As noted in box B, recent EPA tests of two commercial products applied to contaminated beaches in Alaska concluded that, during the period of testing, there was no advantage from their use [77]. In a well-publicized attempt to demonstrate seeding at sea, one company applied microorganisms to oil from the 1990 Mega Borg spill in the Gulf of Mexico [78]. Although the experiment aroused some interest, the results were inconclusive and illustrated the difficulty of conducting a controlled bioremediation experiment at sea and measuring the results. Although there were changes observed in the seeded oil, in the absence of controls the experiment could not tell whether they were due to biodegradation or bioemulsification (the process in which microbes assist the dispersal of surface oil), or were unrelated to the seeding. (Even if bioemulstilcation rather than biodegradation was the process at work in this experiment, it may be of potential interest for oil spill response and could be investigated further.) An attempt has been made to apply a seed culture to a polluted salt marsh $[78,79]$. In July 1990 the Greek tanker Shinoussa collided with three barges in the Houston Ship Channel, resulting in a spill of about 700,000 gallons of catalytic feed stock, partially refined oil. Some of this oil impacted neighboring Marrow Marsh. Microbes were applied to experimental areas within the marsh, and control areas were established. Visual observations made by the scientific support coordinator who monitored the application for the National Oceanic and Atmospheric Administration (NOAA) indicated that treated oil changed color within a few minutes to a few hours after treatment, but that after several days there were no significant visual differences between treated and untreated plots.

More importantly, chemical analyses indicated "no apparent chemical differences in petroleum hydrocarbon patterns between treated and untreated plots several days after treatment $[70,80]$. Not all of the monitoring data have been analyzed yet, so a final determination of effectiveness has not been made. Seed cultures may be most appropriate for situations in which native organisms are either present as slow growers or unable to degrade a particular hydrocarbon. Especially difficult-to-degrade petroleum components, such as polynuclear aromatic hydrocarbons, might be appropriate candidates for seeding [80]. In other cases, if a time advantage can be realized; there may be some utility in seeding with a culture consisting of indigenous organisms [81]. Thus, the potential environmental adaptation problems of nonindigenous organisms might be avoided. In many cases, fertilizers would also have to be added. Seeding may offer promise in environments where conditions can be more or less controlled. In such cases one would have to consider the proper choice of bacteria, a suitable method of application, and suitable site engineering. Arrangements would have to be made for keeping cells moist and in contact with the oil; for protecting them from excess ultraviolet light; for providing adequate nutrients; and for controlling temperature, $\mathrm{pH}$, and salinity. 
However, before claims about the utility of seeding marine oil spills can be proved (or disproved) additional research $[82,83,84]$.

\subsection{Seeding with genetically engineered microorganisms (bioaugmentation with GEMs)}

Although it was not demonstrably superior to indigenous organisms and has never been tested in the field, the frost organism ever patented was a microorganism genetically engineered to degrade oil [82]. The rationale for creating such organisms is that they might possibly be designed either to be more efficient than naturally occurring species or to have the ability to degrade fractions of petroleum not degradable by naturally occurring species. To be effective, such microorganisms would have to overcome all of the problems related to seeding a spill with nonindigenous microbes. EPA has not yet conducted any GEM product reviews for commercial applications, although at least two companies are considering using genetically engineered products for remediating hazardous waste [84, 85]. Since the development and use of GEMs are still limited by scientific, economic, regulatory, and public perception obstacles, the imminent use of bioengineered microorganisms for environmental cleanup is unlikely. Lack of a strong research infrastructure, the predominance of small companies in the bioremediation field, lack of data sharing, and regulatory hurdles are all barriers to the commercial use of genetically engineered organisms [83]. The development of GEMs for application to marine oil spills does not have high priority. Many individuals, including EPA officials, believe that we are so far away from realizing the potential of naturally occurring microorganisms to degrade marine oil spills that the increased problems associated with GEMs render them unnecessary at this time $[86,87,88]$.

\section{Field evaluation of marine oil spill}

There have been several oil spill incidents in which bioremediation products have been used in an attempt to enhance oil biodegradation. In some cases, the response authorities have allowed products to be used for experimental purposes [89]. However, in general, it is difficult to draw valid conclusions from many of these efforts because of the time constraints in planning experiments with appropriate controls after a major spill. Moreover, many of the results are reported second hand with little reliable quantitative information. Despite these limitations, some of these spills have been given as examples of bioremediation success and therefore qualify for scientific appraisal $[90,91]$. One notable exception is the work carried out in the aftermath of the Exxon Valdez spill. The assessments of bioremediation products and techniques are based on experiments carried out with considerable scientific rigor, and the work after the Exxon Valdez incident is therefore given prominence in this section. The scientific results of this research have been only recently published in primary publications and conference proceedings. A majority of the papers were not peer reviewed prior to publication in the scientific literature (a fact that applies to much work conducted after oil spill incidents), and thus the results from these studies should be assessed with caution [92, 93]. 
Also, it is important to emphasize that even in this case, there were significant limitations in the scope of the work. For example, the studies concentrated on North Slope crude oil on cobble shorelines in a high-latitude environment. During the early 1990s, there was an increase in bioremediation field trials associated with accidental spills, largely as a result of the perceived success of the bioremediation program following the Exxon Valdez incident [93]. These are mentioned herein, but many are characterized by having been carried out over a short period and, in some cases, with products in the early stage of development [94].

\subsection{Amoco Cadiz}

On 16 March 1978, the tanker Amoco Cadiz containing 223,000 tones of Arabian Light and Iranian Light crude oil was wrecked off the coast of France. Rough sea conditions resulted in rapid emulsification of the spilled oil, resulting in an increase in the volume of pollutant. Despite efforts to treat the oil at sea, extensive contamination of the shoreline occurred. Most of the beach cleanup effort focused on pumping and mechanical recovery, particularly during the first few weeks of the operation when there was a thick emulsion on the sand and rocks and in the crevices between the rocks. These operations caused some oil to penetrate the sand. In some places, oily sand was overlaid with clean sand deposited as a result of natural coastal processes. Repeated ploughing and harrowing were used to clean the intertidal zone, and four different products were tested to assess the possibility of promoting the biodegradation of oil trapped in sand [95]: (i) a commercial cleaning compound containing nutrients especially adapted to restore oiled soils; (ii) a mixture of lyophilized adapted bacteria, dispersant, and nutrient; (iii) a chemical fertilizer used in agriculture; and (iv) a talc treated with $0.1 \%$ of surfactant. The approaching tourist season seems to have prevented extended experimentation, and other techniques were used to complete the cleanup operations. Hence, the limited results were inconclusive $[95,96]$. Some changes in oil content were found in these experiments, but it was not clear if the removal was physically or biologically mediated.

\subsection{Apex barge}

On 28 July 1990, the Greek tanker Shinoussa collided with two Apex tank barges in the Houston Ship Channel, Galveston Bay, Tex., causing a release of approximately 3,000 $\mathrm{m}^{3}$ of partially refined catalytic feedstock oil over 2 days, which spread onto the surrounding coastline. Alpha BioSea (Alpha Environmental, Houston, Tex.), a product composed of a lyophilized bacterial mixture and inorganic phosphorus and nitrogen nutrients, was applied 8 days after the spill in selected areas of Pelican Island and Marrow Marsh [97, 98]. Two plots on the beach were treated, and two were left untreated as controls. The 15-m diameter experimental plots (separated by 45 to $75 \mathrm{~m}$ ) were sampled on a routine basis [99]. The results of the detailed chemical analysis showed that there were no significant differences between pre- and post treatment samples after $96 \mathrm{~h}$ of treatment with any of the selected methods. Although visual signs indicated that the condition of the marsh areas improved after treatment [100], there was no conclusive evidence to show significant degradation of the oil within the 4-day monitoring period. Numerous compromises in the experimental design of this study have been identified [99]. For example, the separation of treated and untreated plots and the booming methods used 
to isolate them may not have prevented mixing and cross-contamination Furthermore, our knowledge from previous laboratory studies and field trials suggests that the 96-h duration of the experiment was insufficient for a definitive test of bioremediation. Unfortunately, no attempt was made to establish which factor (if any) was limiting biodegradation and what the most appropriate bioremediation strategy might be.

\subsection{Mega Borg}

On 8 June 1990, the Norwegian tanker Mega Borg was carrying out a lightering operation with the Italian tanker Fraqmura about 57 miles off the Texas coast. Following an explosion and fire, the Fraqmura carried out an emergency breakaway operation from the Mega Borg, which resulted in the release of approximately $45 \mathrm{~m} 3$ of Angolan Palanca crude oil [101]. The next day, further oil was lost before the situation was controlled. While it was initially predicted that no oil would reach the shoreline, the Louisiana coast was littered with tiny tar balls 16 days after the accident (55). In terms of bioremediation strategies, the On-Scene Coordinator granted permission to conduct a field trial 1 day after the accident occurred. Two portions of the slick were treated with a product containing Alpha BioSea [102]. A 16-hectare patch of slick located about $5 \mathrm{~km}$ from the Mega Borg was treated 7 days after the accident with $50 \mathrm{~kg}$ of microbial agent (Alpha BioSea) which had been rehydrated with seawater. The product was applied with the standard shipboard fire-hose system. The equipment and treatment preparation time of approximately $1 \mathrm{~h}(105)$ indicates that very little rehydration time was given to the product. Four traverses of the treatment area were made over a 30-min period. Following large-scale application of the product at sea, visual observations indicated that the treated oil changed from a continuous film of brown oil and sheen to discrete areas of mottled brown and yellow material and sheen. An aerial reconnaissance $16 \mathrm{~h}$ after treatment was not able to detect oil in the area. However, there is considerable uncertainty about the fate of the treated oil [102]. The measurements on water samples from the treated slick showed no evidence of acute toxicity to marine life or significantly elevated levels of nutrients or total hydrocarbons. Attempts to assess the effect of the microbial agent from measurements of oil content in the emulsion samples were unsuccessful because of sample variability. By $8 \mathrm{~h}$ after treatment, the slick had largely broken up and dissipated. Although little change was observed in the control area, conclusive evidence of bioremediation effectiveness was not achieved because of limitations in the sampling strategy and the chemical evidence obtained. This study demonstrated the potential problems with the application of bioremediation products at sea, including difficulties with uniform product application, representative sampling, and uncertainties about the ultimate fate of the oil. The short periods over which monitoring are often possible may not be sufficient to validate the presence and activity of oil-degrading bacteria or the effectiveness of bioremediation treatments. The observed visual effects may well have been caused by physical or chemical processes such as surfactant action associated with the treatment [102].

\subsection{Prall's Island}

In January 1990, fuel oil from a pipeline failure spilled into the Arthur Kill waterway in New Jersey and contaminated a gravel beach on the Prall's Island bird sanctuary. Mechanical 
methods were used to remove the bulk of the oil. Cleanup was suspended in March 1990 to minimize possible adverse effects on migrating birds. However, Exxon was granted permission to carry out a bioremediation experiment on part of a contaminated beach. Two shallow trenches were dug in the intertidal zone to bury bags of beach substrate containing known concentrations of oil and to help overcome possible problems of variable distribution of oil on the beach. A slow-release fertilizer (Customblen, Sierra Chemicals) was placed in the trenches to encourage biodegradation. Over a 92-day period, sub samples were periodically taken from the oiled bags, together with beach samples and water samples for analysis of total petroleum hydrocarbons, GC-MS detection of hydrocarbons, microbial counts, and water quality (nitrogen, phosphorus, ammonia, and dissolved oxygen) determination. No clear trends of increased biodegradation from the fertilized plots could be identified during the experiment, and there was high variability in the levels of total petroleum hydrocarbons, which may have masked any effects of the treatment [89].

\subsection{Seal Beach}

On 31 October 1990, a well blowout off Seal Beach, Calif., resulted in the release of approximately $2 \mathrm{~m}^{3}$ of crude oil that contaminated 8,000 to $12,000 \mathrm{~m}^{2}$ of marsh grassland in the Seal Beach National Wildlife Refuge. One week after the incident, the marsh was hand sprayed with a combination of a microbial product used in sewage treatment plants (INOC 8162) and a commercial fertilizer (Miracle Gro 30-6-6). Two weeks later, the fertilizer alone was applied. Oiled, oiled and treated, and unoiled samples were collected and analyzed for oil content by GC-MS [89].

Measurements were also made of the microbial mineralization of the phenanthrene, microbial respiration, and biomass. The results of a 35-day monitoring effort showed no differences between the treated and untreated oil plots. Subsequently, laboratory tests were carried out with the microbial product and Prudhoe Bay crude oil to compare the performance of the microbial product with nutrient-only controls. After 16 days of incubation, little or no difference was found between treated and control flasks. It was concluded that the microbial product was not effective in accelerating biodegradation of oil under controlled laboratory conditions [89].

Moreover, the salt marsh environment may be difficult to bioremediate simply by adding sources of nitrogen and phosphorus. Oxygen depletion may have been a significant factor in the inhibition of oil biodegradation [103].

\subsection{Exxon Valdez}

The tanker Exxon Valdez ran aground on Bligh Reef in the Gulf of Alaska on 24 March 1989, spilling approximately 41,000 $\mathrm{m}^{3}$ of Alaskan North Slope crude oil (primarily Prudhoe Bay crude oil). A major response effort was mounted at sea to recover the oil, but the prevailing conditions and circumstances resulted in the contamination of about 2,090 km of coastline [104]. Some beaches were heavily oiled, particularly those on islands in Prince William Sound that were directly in the path of the slick. Many techniques were adopted 
in a massive effort to clean up the shoreline of the Sound $(72 \%$ rock face, $24 \%$ mixed boulder and cobble, $3.5 \%$ mixed cobble and pebble, and $0.5 \%$ fine-grain sand/mud or marsh). These included cold- and warm-water washing, steam cleaning, and manual oil recovery techniques. Initially, the main aim was to remove the heaviest concentrations of oil to minimize the impact on wildlife and fisheries [104, 105]. A bioremediation option based on nutrient enrichment was proposed shortly after the spill. However, it was thought necessary to carry out some research first to establish the potential for effective and safe use of this technique. The limited success of the initial field tests led to the approval of full-scale application in August 1989, and $119 \mathrm{~km}$ of shoreline was subsequently treated that year. By 1990, the previous cleanup efforts and winter storms had greatly reduced the extent of shoreline oiling [106] and natural recovery processes were already well advanced [7, 8]. The National Oceanic and Atmospheric Administration applied the concept of net environmental benefit analysis in an evaluation of the main alternative to bioremediation at this time, namely, excavation and rock-washing treatment [107].

It was concluded that this technique would be particularly damaging to the environment. Bioremediation was therefore adopted as a prime cleanup strategy. In 1990 and 1991, bioremediation was used in combination with storm berm relocation, tilling, and manual pickup. On 12 June 1992, the U.S. Coast Guard and the State of Alaska declared the cleanup officially concluded on the basis that there would be no further net environmental benefit from continuing the effort.

Shortly after the Exxon Valdez spill, it was suggested that bioremediation may be able to enhance the rates of oil removal from the contaminated beaches [108]. As a preliminary step, the number of oil degrading microorganisms on oiled beaches in comparison with untreated controls was determined. Pritchard et al. (2005) reported that the hydrocarbon-degrading microorganisms on oiled shorelines had increased by as much as 10,000 times to an average level of 106 cells per $g$ of beach material. Once it was clear that hydrocarbon degraders were present in abundance, it was necessary to establish which factors were likely to limit biodegradation and which specific hydrocarbon components were biodegradable. The research was conducted in the laboratory with Prudhoe Bay crude oil weathered by distillation to remove the volatile fraction. Biodegradation by indigenous microorganisms was monitored by noting changes in the concentration of components of the oil by GC-MS, by monitoring carbon dioxide evolution and oxygen consumption by the microorganisms, and by determining the evolution of radioactive $14 \mathrm{CO}_{2}$ from specific $14 \mathrm{C}$-labeled oil components such as phenanthrene [109].

The experiments demonstrated unequivocally that the microbial population in Prince William Sound could rapidly biodegrade the aliphatic and aromatic fractions of Prudhoe Bay crude in the presence of suitable nitrogen and phosphorus sources. The microbial community decomposed $\mathrm{C} 1$ dibenzothiphene, $\mathrm{C}_{2}$ fluorenes, $\mathrm{C}_{3}$ naphthalenes, phenanthrene, and anthracene among others (113). Studies of $\mathrm{CO}_{2}$ production suggested that the oil was not just being biotransformed but that it was being completely mineralized to $\mathrm{CO}_{2}$ and $\mathrm{H}_{2} \mathrm{O}$. For example, over $30 \%$ of [U-14C]phenanthrene could be mineralized to $14 \mathrm{CO}_{2}$ within 4.5 days when incubated with oil-contaminated beach material from Prince William Sound [83]. 
The highest mineralization rates were noted in the test systems treated with the highest concentration of nitrogen. From these results, it is clear that the main factor limiting the biodegradation of oil on the beaches in Prince William Sound was the concentration of nutrients, particularly nitrogen. A substantial microbial biomass had already developed in the contaminated areas of Prince William Sound which was able to decompose many components within the contaminant oil. Hence, addition of nutrients, and not seeding, was thought to be the most appropriate bioremediation strategy [17, 80].

\section{Conclusion and future prospects}

Despite the growing acceptance of bioremediation as a means to treat spilled oil in marine environments the mechanisms that promote the process under field conditions remain poorly constrained. Although general statements can be made regarding the enhancement of biodegradation by nutrient amendment, there is no consensus on how to best optimize nutrient additions. Subsequently, oil spill treatment strategies are largely developed empirically from previous experience and/or from laboratory feasibility studies. Introduction of a theoretical framework to explain observations from primarily empirical studies of oil-spill bioremediation would be a fundamental step towards the development of more objective spill management practices. Resource ratio theory has recently been put forward as a theoretical basis to explain some of the effects of bioremediation and many of the observations made in bioremediation studies are consistent with the theory's predictions. Although the introduction of this theory may simply augment current empirical approaches, in the longer term it has the potential to form the basis of more predictable bioremediation strategies, and the introduction of theory to the field of bioremediation is an important progression. To further test the applicability of resourceratio theory it will be necessary to conduct systematic studies on the effect of different nutrient amendments on bacterial populations and concomitant alterations in biodegradation rates, to identify patterns of microbial diversity associated with optimum contaminant removal. Until recently, such an approach would not have been possible due to the limitations of the methods available to characterize the composition of microbial communities. With the introduction of molecular methods to study indigenous microorganisms, this limitation has been alleviated to some extent. Integrated studies combining careful field evaluation of crude oil biodegradation with molecular approaches to study microbial populations involved in degradation of spilled oil have already begun and promise to reveal much regarding the relationship between microbial population structure and the progress of bioremediation. Anaerobic hydrocarbon degradation in marine environments has only recently been widely accepted and there is a need to determine both how widespread an occurrence this is and in what circumstances it will have a significant impact on the dissipation of crude oil contamination. The environmental factors that promote the process must also be identified if it is to be exploited for the treatment of spilled oil. 


\section{Author details}

Mehdi Hassanshahian ${ }^{1^{*}}$ and Simone Cappello ${ }^{2,3^{*}}$

*Address all correspondence to: mshahi@uk.ac.ir

1 Department of Biology - Faculty of Science- Shahid Bahonar University of Kerman - Kerman, Iran

2 Istituto per l'Ambiente Marino Costiero (IAMC) - C.N.R. U.O.S. di Messina, Italy

3 Istituto Sperimentale Talassografico (IST) di Messina, Italy

\section{References}

[1] Alloway BJ, Ayres DC. Organic Pollutants. In: Chemical Principles of Environmental Pollution. 1st edition. Chapman and Hall, India; 1993.

[2] Atlas RM. Microbial degradation of petroleum hydrocarbons: an environmental perspective. Microbiology Review 1981; 45 180-209.

[3] Marshall AG, Rogers RP. Petroleomics: the next grand challenge for chemical analysis. Analytical Chemistry Research 2003; 37 53-59.

[4] Head IM, Jones DM Larter S R. Biological activity in the deep subsurface and the origin of heavy oil. Nature 2003; 426344-352.

[5] Texas B. In Proceedings of the Fifteenth Arctic and Marine Oil Spill Program Technical Seminar. Canada Ottawa Canada, 2001.

[6] Cappello S, Denaro R, Genovese M, Giuliano L, Yakimov MM. Predominant growth of Alcanivorax during experiments on oil spill bioremediation in mesocosms. Microbiology Research 2006; 162 185-190.

[7] National Research Council. Oil in the Sea III: Inputs, Fates and Effects. National Academy of Sciences Washington DC; 2002.

[8] Mahon A, Labelle RP. Update of comparative occurrence rates for offshore oil spills. Spill Science Technology Bulletin 2000; 6 303-321.

[9] Cappello S, Caruso G, Zampino D, Monticelli LS, Maimone G, Denaro R, Tripodo B, Troussellier M, Yakimov MM, Giuliano L. Microbial community dynamics during assays of harbour oil spill bioremediation: a microscale simulation study. Journal of Applied Microbiology 2007. 102 (1), 184-194.

[10] Department of the Environment. Transport and the Regions: Digest of Environmental Statistics. London HMSO; 1998. 
[11] Prince RC. Bioremediation of oil spills. Trends Biotechnology 1997, 15158-160.

[12] Swannell RPJ, Lee K, McDonagh M. Field evaluations of marine oil spill bioremediation. Microbiology Review 1996; 60 342-365.

[13] Cappello S, Gabriella G, Vivia B. Crude oil-induced structural shift of coastal bacterial communities of rod bay and characterization of cultured cold-adapted hydrocarbonoclastic bacteria. FEMS Microbiology Ecology 2004; 49 419-432.

[14] Cappello S, Crisari A, Hassanshahian M, Genovese M, Santisi S, Yakimov MM. “Effect of a Bioemulsificant Exopolysaccharide (EPS2003) on Abundance and Vitality of Marine Bacteria." Water Air Soil Pollution 2012; DOI 10.1007/s11270-012-1159-8.

[15] U.S. Environmental Protection Agency. Interim report. Oil Spill Bioremediation Project. Office of Research and Development, U.S. Environmental Protection Agency 1990; Gulf Breeze, Fla.

[16] Cappello S, Genovese M, Torre CD, Crisari A, Hassanshahian M, Santisi S, Calogero R, Yakimov MM. Effect of bioemulsificant exopolysaccharide (EPS2003) on microbial community dynamics during assays of oil spill bioremediation: A microcosm study. Marine Pollution Bulletin 2012; http://dx.doi.org/10.1016/j.marpolbul.2012.07.046.

[17] Cappello S, Santisi S, Calogero R, Hassanshahian M, Yakimov MM. Characterization of Oil-Degrading Bacteria Isolated from Bilge Water. Water Air Soil Pollution 2012; 223 3219-3226.

[18] Caruso G, Denaro R, Genovese M, Giuliano L, Mancuso M, Yakimov MM. New methodological strategies for detecting bacterial indicators. Chemistry and Ecology 2004; 20 (3) 167-181.

[19] Kohno T, Sugimoto Y, Sei K, Mori K. Design of PCR Primers and gene probes for general detection alkane-degrading bacteria. Microbes and Environment 2002; 17 (3) 114-212.

[20] Hassanshahian, M., Emtiazi, G., Kermanshahi, R., Cappello, S. 2010. Comparison of oil degrading microbial communities in sediments from the Persian Gulf and Caspian Sea. Soil and Sediment Contamination. 19 (3), 277-291.

[21] Das K, Ashis K, Mukherjee F. Crude petroleum-oil biodegradation efficiency of Bacillus subtilis and Pseudomonas aeruginosa strains isolated from a petroleum-oil contaminated soil from North-East India. Bioresource Technology 2006; 98 1339-1345.

[22] Naughton SJ, Stephen JR, Venosa AD, Davis GA, Chang Y-J, White DC. Microbial population changes during bioremediation of an experimental oil spill. Applied Environmental Microbiology 1999, 65 3566-3574.

[23] Söhngen NL. Benzin Petroleum, Paraffinöl und Paraffin als Kohlenstoff- und Energiequelle für Mikroben. Zentralbl. Bakteriol 1913; 237 595-609 (in German). 
[24] Prince RC. Petroleum Microbiology. American Society for Microbiology Press Washington DC; 2005.

[25] Emtiazi G, Hassanshahian M, Golbang N. Development of a microtiter plate method for determination of phenol utilization, biofilm formation and respiratory activity by environmental bacterial isolates. International Biodeterioration \& Biodegradation $2005 ; 56$ 231-235.

[26] Hedlund BP, Geiselbrecht AD, Bair TJ, Staley JT. Polycyclic aromatic hydrocarbon degradation by a new marine bacterium, Neptunomonas naphthovorans gen. nov., sp. nov. Applied Environmental Microbiology 1999; 65 251-259.

[27] Emtiazi G, Saleh T, Hassanshahian M. The effect of bacterial glutathione S-transferase on morpholine degradation. Biotechnology Journal 2009 ; 4, 202-205.

[28] Chaillana F, Flècheb A, Burya E, Phantavonga Y, Saliot A, Oudot J. Identification and biodegradation potential of tropical aerobic hydrocarbon-degrading microorganisms. Research Microbiology 2004; 155(7) 587-595.

[29] Lliros M, Munill X, Sole A, Martinez-Alonso M, Diestra E, Esteve I. Analysis of cyanobacteria biodiversity in pristine and polluted microbial mats in microcosms by confocal laser scanning microscopy (CLSM). Science Technology and Education of Microscopy 2003; 52 483-499.

[30] Barth HJ. The influence of cyanobacteria on oil polluted intertidal soils at the Saudi Persian Gulf shores. Marine Pollution Bulletin 2003; 46 1245-52.

[31] Hassanshahian M, Emtiazi G, Cappello S. Isolation and characterization of crude-oildegrading bacteria from the Persian Gulf and the Caspian Sea. Marine Pollution Bulletin 2012; 64 7-12.

[32] Ghanavati H, Emtiazi G, Hassanshahian M. Synergism effects of phenol degrading yeast and Ammonia Oxidizing Bacteria for nitrification in coke wastewater of Esfahan Steel Company. Waste Management \& Research 2008; 26(2) 203-208.

[33] Yakimov MM, Golyshin PN, Lang S, Moore ER, Abraham WR, Lunsdorf H, Timmis KN. Alcanivorax borkumensis gen. nov., sp. nov., a new hydrocarbon-degrading and surfactant producing marine bacterium. International Journal Systematic Bacteriology 1998; 48 339-348.

[34] Dyksterhouse SE, Gray JP, Herwig RP, Lara JC, Staley JT. Cycloclasticus pugetii gen. nov., sp. nov., an aromatic hydrocarbon-degrading bacterium from marine sediments. International Journal Systematic Bacteriology 1995; 45 116-123.

[35] Gauthier MJ, Lafay B, Christen R, Fernandez L, Acquaviva M, Bonin P, Bertrand JC: Marinobacter hydrocarbonoclasticus gen. nov., sp. nov., a new extremely halotolerant, hydrocarbondegrading marine bacterium. Int J Syst Bacteriol 1992, 42:568-576.

[36] Golyshin PN, Chernikova TN, Abraham WR, Lunsdorf H, Timmis KN, Yakimov MM. Oleiphilaceae fam. nov., to include Oleiphilus messinensis gen. nov., sp. nov., a 
novel marine bacterium that obligatory utilizes hydrocarbons. International Journal Systematic Bacteriology 2002; 52 901-911.

[37] Yakimov MM, Giuliano L, Gentile G, Crisafi E, Chernikova TN, Abraham WR, Lunsdorf H, Timmis KN, Golyshin PN. Oleispira antarctica gen. nov., sp. nov., a novel hydrocarbonoclastic marine bacterium isolated from Antarctic coastal sea water. International Journal Systematic Evolutionary Microbiology 2003; 53 779-785.

[38] Engelhardt MA, Daly K, Swannell RP, Head IM. Isolation and characterization of a novel hydrocarbon-degrading, Gram positive bacterium, isolated from intertidal beach sediment, and description of Planococcus alkanoclasticus sp. nov. Journal Applied Microbiology 2001; 90 237-247.

[39] Melcher RJ, Apitz SE, Hemmingsen BB. Impact of irradiation and polycyclic aromatic hydrocarbon spiking on microbial populations in marine sediment for future aging and biodegradability studies. Applied Environment Microbiology 2002; 68 2858-2868.

[40] Zhuang WQ, Tay JH, Maszenan AM, Tay ST. Isolation of naphthalene-degrading bacteria from tropical marine sediments. Water Science Technology 2003; 47 303-308.

[41] Gilewicz M, Nimatuzahroh T, Nadalig H, Budzinski P, Doumenq V, Michotey JC, Bertrand JC. Isolation and characterization of a marine bacterium capable of utilizing 2-methylphenanthrene. Applied Microbiology Biotechnology 1997; 48 528-533.

[42] Button DK, Schut F, Quang P, Martin R, Robertson BR. Viability and isolation of marine bacteria by dilution culture: theory, procedures, and initial results. Applied Environmental Microbiology 1993; 59 881-891.

[43] Atlas RM. Petroleum Microbiology. Macmillan Publishing New York; 1984.

[44] Gibson DT. Microbial Degradation of Organic Compounds. Dekker New York; 1984.

[45] Ensign SA. Microbial metabolism of aliphatic alkenes. Biochemistry 2001; 40 58455853.

[46] Van Beilen JB, Wubbolts MG, Witholt B. Genetics of alkane oxidation by Pseudomonas oleovorans. Biodegradation 1994; 5 161- 174.

[47] Atlas RM, Bartha R. Inhibition by fatty acids of the biodegradation of petroleum. Antonie van Leeuwenhoek 1973; 39 257-271.

[48] Cerniglia CE. Biodegradation of polycyclic aromatic hydrocarbons. Biodegradation 1992; 3 351-368.

[49] Maneerat S, Kulnaree P. Isolation of biosurfactant-producing marine bacteria and characteristics of selected biosurfactant. Applied Microbiology 2007; 29 783-791.

[50] Mathew M. Obbard JP. Optimization of the dehydrogenase assay for measurement of indigenous microbial activity in beach sediments contaminated with petroleum. Biotechnology Letters 2001; 23 227-230. 
[51] Evans WC, Fuchs G. Anaerobic degradation of aromatic compounds. Annual Review Microbiology 1988; 42 289- 317.

[52] Pruthi V, Cameotra SS. Rapid identification of biosurfactant-producing bacterial strains using a cell surface hydrophobicity technique. Biotechnology Techniques $1997 ; 11$ 671-674.

[53] Aeckersberg F, Bak F, Widdel F. Anaerobic oxidation of saturated hydrocarbons to carbon dioxide by a new type of sulfate-reducing bacterium. Archive Microbiology $1991 ; 1565-14$.

[54] Spormann AM, Widdel F. Metabolism of alkylbenzenes, alkanes, and other hydrocarbons in anaerobic bacteria. Biodegradation 2000; 11 85- 105.

[55] Anderson RT, Lovley DR. Hexadecane decay by methanogenesis. Nature 2000; 404, 722-723.

[56] So CM, Phelps CD, Young LY. Anaerobic transformation of alkanes to fatty acids by a sulfate-reducing bacterium, strain Hxd3. Applied Environmental Microbiology 2003; 69 3892-3900.

[57] Edwards EA, Grbic-Galic D. Anaerobic degradation of toluene and o-xylene by a methanogenic consortium. Applied Environmental Microbiology 1994; 60 313-322.

[58] Wilkes H, Rabus R, Fischer T, Armstroff A, Behrends A, Widdel F. Anaerobic degradation of $n$-hexane in a denitrifying bacterium: further degradation of the initial intermediate (1-methylpentyl) succinate via C-skeleton rearrangement. Achieve Microbiology 2002; 177 235- 243.

[59] Tannenbaum E, Starinsky A, Aizenshtat Z. Light-oils transformation to heavy oils and asphalts-assessment of the amounts of hydrocarbons removed and the hydrological-geological control of the process. Exploration for Heavy Crude Oil and Natural Bitumen. The American Association of Petroleum Geologists 1987, Tulsa, Oklahoma

[60] Sorkhoh NA, Ghannoum MA, Ibrahim AS, Stretton RJ, Radwan S. Crude oil and hydrocarbon-degrading strains of Rhodococcus rhodochrous isolated from soil and marine environments in Kuwait. Environmental Pollution 1990; 651 - 17.

[61] Hfpner T, Felzmann H, Struck H, van Bernem KH. The nature and extent of oil contamination on Saudi Persian Gulf beaches: examinations of beaches of Dawhat ad Dafi and Dawhat ad Musallamiya in summer 1991 and winter 1991/92. Arab Journal Science Engineering 1993; 18 243-255.

[62] Hasanshahian M, Emtiazi G. Investigation of alkane biodegradation using the microtiter plate method and correlation between biofilm formation, biosurfactant production and crude oil biodegradation. International Biodeterioration \& Biodegradation 2008; 62 170-178. 
[63] Hassanshahian M, Tebyanian H, Cappello S. Isolation and characterization of two crude-oil degrading yeast strains, Yarrowia lipolytica PG-20 and PG-32 from Persian Gulf. Marine Pollution Bulletin 2012; 64 1386-1391.

[64] Kubota M, Nodate M, Yasomoto H, Taku U, Osamu K, Misawa R. Isolation and functional analysis of cytochrom P450 genes from various environment. Biosience Biotechnology and Biochemistry 2005; 69 (12) 2421-2430.

[65] Lebaron P, Servais P, Trousellier M. Changes in bacterial community structure in seawater mesocosms differing in their nutrient status. Acquatic Microbial Ecology 1999; 19 255-267.

[66] Kloos J, Charles M, Schloter M. New method for the detection of alkane-monooxygenase homologous genes (alkB) in soils based on PCR-hybridization. Journal of Microbiological Methods 1999 ; 66 486-496.

[67] Lee M, Hwang G, Hung J, Young K, Kyung H. Physical structure and expression of alkb encoding alkane hydroxylase and rubredoxin reductase from Pseudomonas maltophilia. Biochemical and Biophysical Research Communications 1996; 218 17-21.

[68] Pukall R, Pauker O, Buntefu BD, Ilichs G, Lebaron P, Bernard, L, Guindulain T, Vives-Rego J, Stackebrandt E. High sequences diversity of Alteromonas macleodii-related cloned and cellular 16S rDNAs from Mediterranean seawater mesocosm experiment. FEMS Microbiology Ecology 1999; 28 335-344.

[69] Radwan SS, Al-Hasan RH, Salamah A, Khanafer M. Oil-consuming microbial consortia floating in the Persian Gulf. International Biodeterioration \& Biodegradation 2005; 56 28-33.

[70] Li ZY, Kravchenko I, Xu H, Zhang C. Dynamic changes in microbial activity and community structure during biodegradation of petroleum compounds: A laboratory experiment. Journal of Environmental Science 2007; 19 1003-1013.

[71] Liu C, Zongze S. Alcanivorax dieselolei sp. nov., a novel alkane-degrading bacterium isolated from sea water and deep-sea sediment. International Journal of Systematic and Evolutionary Microbiology 2005; 55 1181-1186.

[72] Maa FB, Jing B, Guo L, Zhao C, Chein-chi C, Di C. Application of bioaugmentation to improve the activated sludge system into the contact oxidation system treating petrochemical wastewater. Bioresource Technology 2009; 100 597-602.

[73] Macnaughton S J, Stephen JR, Venosa AD, Davis GA, Chang YJ, White DC. Microbial population changes during bioremediation of an experimental oil spill. Applied and Environmental Microbiology 1999; 65 3566-3574.

[74] Rahman KSM, Thahira-Rahman J, Lakshmanaperumalsamy P, Banat IM. Towards efficient crude oil degradation by a mixed bacterial consortium. Bioresource Technology 2004; 85 257-261. 
[75] Makrarn T. Suidan Effects of nitrogen source on crude oil biodegradation. Journal of Industrial Microbiology 1994; 13 279-286.

[76] Malatova A, Sbirova P, Rastosdia R. Isolation and characterization of hydrocarbon degrading bacteria from enviromental habitats in western New York State. Journal of Applied Microbiology 2005; 65 780-790.

[77] Manee P, Prayad P, Edward S, Upatham A, Ladda T. Biodegradation of crude oil by soil microorganisms in the tropic. Biodegradation 1998; 9 83-90.

[78] Margesin R, Labbe D, Schinner FC, Greer W, Whyte LG. Characterization of hydrocarbon-degrading microbial populations in contaminated and pristine alpine soils. Applied and Environmental Microbiology 2003; 69 3085-3092.

[79] Margesin R, Feller G, Hämmerle M, Stegner U, Schinner F. colorimetric method for the determination of lipase activity in soil. Biotechnology Letters 2002; 24 27-33.

[80] Marquez MC, Ventosa A. Marinobacter hydrocarbonoclasticus Gauthier et al. 1992 and Marinobacter aquaeolei Nguyen et al. 1999 are heterotypic synonyms. International Journal of Systematic and Evolutionary Microbiology 2005; 55 1349-1351.

[81] Mckew B, Coulon F, Yakimov MM, Denaro R, Genovese M, Smith J, Osborn M, Timmis KN, Mcgenity TJ. Efficacy of intervention strategies for bioremediation of crude oil in marine systems and effects on indigenous hydrocarbonoclastic bacteria. Environmental Microbiology 2007; 9 (6) 1562-1571.

[82] Muratova AY, Turkovskaya V. Degradation of petroleum oils by a selected microbial association. Applied Biochemistry and Microbiology 2001; 37 155-159.

[83] Muyzer G, Kornelia S. Application of denaturing gradient gel electrophoresis (DGGE) and temperature gradient gel electrophoresis (TGGE) in microbial ecology. Antonie van Leeuwenhoek 1998; 73 127-141.

[84] Muyzer G, Waal EC, Uitterlinden AG. Profiling of complex microbial populations by denaturing gradient gel electrophoresis analysis of polymerase chain reaction-amplified genes encoding for $16 S$ rRNA. Applied and Environmental Microbiology 1993; $59,695-700$.

[85] Nakamuraa S, Sakamotoa Y, Ishiyamaa M, Tanakaa M, Kuniib K, Kubob C, Sato P. Characterization of two oil-degrading bacterial groups in the Nakhodka oil spil. International Biodeterioration \& Biodegradation 2007; 60 202-207.

[86] Narhi LO, Wen LP, Fulco AJ. Characterization of the protein expressed in Escherichia coli by a recombinant plasmid containing the Bacillus megaterim cytochrome P-450 BM-3 gene. Molecular Cell Biochemistry 1988; 79 63-71.

[87] Nodate M, Mitsutoshi K, Norihiko M. Functional expression system for cytochrome P450 genes using the reductase domain of self-sufficient P450RhF from Rhodococcus sp. NCIMB 9784. Applied Microbiology Biotechnology 2006; 71 455-462. 
[88] Odum EP. The mesocosm. Bioscience 1984; 34 558-562.

[89] Okerentugba PO, Ezeronye OU. Petroleum degrading potentials of single and mixed microbial cultures isolated from rivers and refinery effluent in Nigeria. African Journal of Biotechnology 2003; 2 (9) 288-292.

[90] Hoff R. A summary of bioremediation applications observed at marine oil spills. Report HMRB 91-2. Hazardous Materials Response Branch, National Oceanic and Atmospheric Administration 1991; Washington DC.

[91] Petersen JE, Cornwell JC, Kemp WM. Implicit scaling in the design of experimental aquatic ecosystems. Oikos 1999; 85 3-18.

[92] Powell SM, Ferguson SH, Bowman P, Snape I. Using real-time PCR to assess changes in the hydrocarbon-degrading microbial community in antarctic soil during bioremediation. Microbial Ecology 2006; 52 523-532.

[93] National Academy of Sciences. Oil in the Sea: Inputs, Fates and Effects. Washington DC: National Academy Press; 1985.

[94] Hoff R. Bioremediation: an overview of its development and use for oil spill cleanup. Marine Pollution Bulletin 1993; 26 476-481.

[95] Atlas RM. Microbial hydrocarbon degradation-bioremediation of oil spills. Journal Chemistry Technology Biotechnology 1991; 52 149-156.

[96] Bocard CP, Renault J, Croquette S. Cleaning products used in operations after the Amoco Cadiz disaster. In Proceedings of the International Oil Spill Conference. American Petroleum Institute 1979; Washington D.C.

[97] Pruthi V, Cameotra S S. Rapid identification of biosurfactant-producing bacterial strains using a cell surface hydrophobicity technique. Biotechnology Techniques $1997 ; 11671-674$.

[98] Mearns A J. 1991. Observations of an oil spill bioremediation activity in Galveston Bay, Texas. NOAA Technical Memorandum NOS OMA 57. National Oceanic and Atmospheric Administration 1997; Washington D.C.

[99] Texas General Land Office. Combating oil spills along the Texas coast: a report on the effect of bioremediation. Texas General Land Office 1989; Austin.

[100] Nadeau R, Singhvi J, Ryabik YH, Lin J, Syslo C. Bioremediation efficacy in Marrow Marsh following the Apex Oil Spill, Galveston 1992.

[101] Greene TC. The Apex Barges spill, Galveston Bay, July 1990, In Proceedings of the 1991 Oil Spill Conference. American Petroleum Institute 1991; Washington, D.C.

[102] Leveille TP. The Mega Borg fire and oil spill: a case study. In Proceedings of the 1991 International Oil Spill Conference. American Petroleum Institute 1991; Washington, D.C. 
[103] Texas General Land Office. Mega Borg oil spill off the Texas coast: an open water bioremediation test. Texas General Land Office 1990; Texas Water Commission Austin 273-278.

[104] Lee K, Levy EM. Bioremediation: waxy crude oils stranded on low-energy shorelines, In Proceedings of the 1991 Oil Spill Conference (Prevention, Behaviour, Control, Cleanup). American Petroleum Institute 1991; Washington, D.C 541-547.

[105] Bragg JR, Prince JB, Wilkinson RM, Atlas D. Biore- 362 SWANNELL ET AL. MICROBIOL. REV. mediation for shoreline cleanup following the 1989 Alaskan oil spill. Exxon Co., USA 1992; Houston.

[106] Owens EH. Changes in shoreline oiling conditions $11 / 2$ years after the 1989 Prince William Sound spill. Technical Report 1991; Woodward-Clyde Consultants, Coastal Science and Engineering Center, Seattle.

[107] Jahns HO, Bragg LC, Dash EH, Owens. Natural cleaning of shorelines following the Exxon Valdez oil spill. In Proceedings of the 1991 Oil Spill Conference. American Petroleum Institute 1991; Washington, D.C., 167-176.

[108] National Oceanic and Atmospheric Administration. Excavation and rock washing treatment technology - net environmental benefit analysis. Hazardous Materials Response Branch, National Oceanic and Atmospheric Administration 1990; Seattle.

[109] Pritchard PH, Costa C. EPA's Alaska oil spill bioremediation project. Environment. Science. Technology 1991; 25 372-379. 
